\title{
PENERAPAN CLOUD ACCOUNTING DALAM MENUNJANG EFEKTIVITAS LAPORAN NERACA PADA PERGURUAN TINGGI
}

\author{
Qurotul Aini ${ }^{1}$, Untung Rahardja ${ }^{2}$, Abdul Hamid Arribathi ${ }^{3}$, Nuke Puji Lestari Santoso ${ }^{4}$ \\ ${ }^{123}$ Dosen Sistem Informasi STMIK RAHARJA \\ ${ }^{4}$ Mahasiswa Sistem Informasi STMIK RAHARJA \\ Jl. Jendral Sudirman No. 40, Modernland, Tangerang \\ Iaini@raharja.info, ${ }^{2}$ untung@raharja.info, ${ }^{3}$ abdulhamid@raharja.info, ${ }^{4}$ nuke@raharja.info
}

\begin{abstract}
Abstrak-Saat berkembangnya era digital 4.0 sudah menjajaki segala bidang, baik bidang pendidikan, teknologi maupun bidang lainnya. Dalam hal laporan keuangan dirasa saat ini sudah harus mengikuti perkembangan tersebut. Dalam hal memudahkan suatu pekerjaan dan resiko yang cukup riskan. Pada Perguruan Tinggi dalam sebuah laporan keuangan yaitu salah satunya laporan neraca masih belum maksimal terhadap pimpinan. Laporan tersebut berupa laporan Neraca pada Perguruan Tinggi Raharja. Penelitian ini menghadapi 2 (dua) permasalahan yaitu perhitungan laporan neraca secara manual dan kekeliruan yang tinggi. Hal ini dapat menghambat laporan keuangan kepada pimpinan setiap bulan. Dalam mencegah permasalahan tersebut dibutuhkan manajemen laporan keuangan yang baik dan tepat. Cloud accounting merupakan pemanfaatan cloud sebagai penyimpanan akuntansi secara online. Dengan digunakannya cloud accounting pada software online jurnal.id data pemasukan dan pengeluaran sudah terinput dengan baik, sehingga data laporan neraca akurat dan cepat. Terdapat menu laporan pada jurnal.id guna mendapatkan data laporan Neraca secara keseluruhan dan akurat. Adanya 7(tujuh) metode sebagai penyelesaian masalah yang digunakan pada penelitian ini. Peneliti berharap dengan adanya manajemen laporan keuangan neraca mampu memudahkan akuntan dalam menyampaikan laporan kepada pimpinan setiap bulan.
\end{abstract}

Kata kunci-Cloud Accounting, Laporan Neraca, Laporan keuangan

\section{PENDAHULUAN}

Pada era industry 4.0 yang semakin berkembang pesat dan cepat terlihat jelas pada Teknologi informasi [1]. Dengan aksi nyata kecanggihan teknologi kini bisa dapat diakses dimana saja dan kapan saja [2]. Perkembangan tersebut mampu mendorong untuk terus belajar dan mengimbangi perubahan agar tidak tertinggal [3]. Institusi Pendidikan saat ini harus semakin berkualitas dalam kinerja keuangan guna mampu mengikuti berkembangannya akuntansi yang menuntut adanya peningkatan akuntanbilitas dan transparansi institusi pendidikan [4].

Laporan keuangan merupakan sarana komunikasi informasi keuangan terhadap pihak-pihak luar korporasi, yang diharapkan mampu mampu memberikan informasi kepada pimpinan guna mengambil keputusan. Menurut Orniati, Laporan keuangan tersebut sangat diperlukan Pimpinan yang telah dianalisis dan berguna sebagai alat pengambilan keputusan untuk masa yang akan datang [5]. Laporan keuangan tahunan yang menjadi sebuah media bagi manajemen institusi kepada pihak yang berkepentingan dan sarana pertanggungjawaban untuk publik atas sumberdaya yang dikelolanya [6]. Terdapat komponen dalam laporan keuangan yang meliputi laporan anggaran, Neraca, Laporan Arus Kas maupun Catatan Laporan Keuangan [7].

Neraca merupakan gambaran kondisi dari suatu keuangan perusahaan atau institusi. Berguna menampilkan keseimbangan keputusan antara investasi dengan pendanaan [8]. Yang dimana menurut Mulyono, pengawasan secara tidak langsung hanya mengawasi dengan permintaan laporan berkala yaitu laporan neraca dan perhitungan laba rugi, perubahan akan arah dan pola keuangan suatu institusi bermanfaat pada rasio keuangan [9].

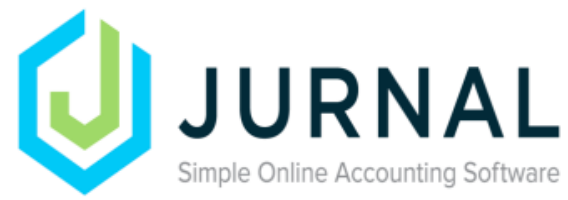

Gbr 1. Software Akuntansi Online Jurna

Software Jurnal merupakan software akuntansi online sebagai penunjang pencatatan sebuah laporan keuangan yang mampu diakses secara online [10]. Manfaat adanya perkembangan tersebut digunakan untuk memudahkan proses pelaksanaan dan mampu meningkatkan efisiensi [11]. Software akuntansi online atau dapat disebut dengan cloud accounting kini hadir yang bisa bermanfaat bagi masyarakat awam dalam mengelola keuangan usaha secara terperinci dengan mudah [12]. Pada masa ini, sangat penting bagi para akuntan dalam memposisikan dirinya dan menciptakan ruang gerak yang lebih independen [13]. 


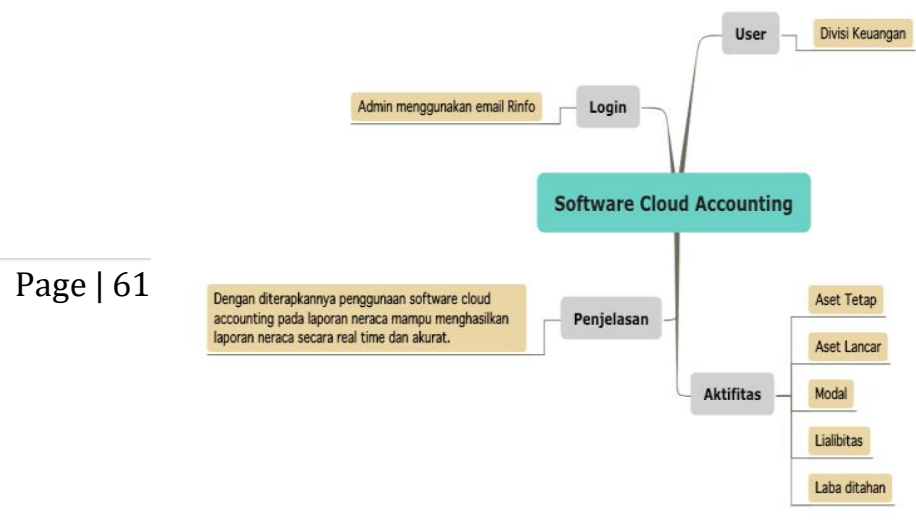

Gbr 2. Mind Mapping Laporan Neraca

Dari gambar 2.2 terdapat 3 (tiga) macam laporan keuangan pada Perguruan Tinggi Raharja yaitu Laporan Laba Rugi, Laporan Arus Kas dan Neraca. Namun, pada penelitian ini mengerucut pada bagian laporan Neraca. Pada laporan Neraca terdapat 5 (lima) penyajian dalam neraca yaitu aset lancar, modal, aset tetap, laba ditahan dan lialibitas. Perlunya integrasi dari berbagai informasi guna mendapatkan data akurat [14].

Permasalahan yang pertama yaitu laporan neraca yang disajikan masih secara konvensional. Dengan dicetak menggunakan kertas, sehingga bisa mengakibatkan tercecernya sebuah laporan dan tidak di arsip dengan baik.

Permasalahan yang kedua yaitu laporan neraca yang masih harus dihitung dengan cara konvensional. Hal ini mengakibatkan bisa terjadinya kekeliruan dalam penjumlahan total neraca. Perubahan sangat diperlukan dalam segala hal termasuk dalam penyajian bentuk informasi, dari cara konvensional menjadi yang lebih modern sehingga dapat memudahkan pembaca dalam memahami informasi yang disajikan [15].

\section{METODE PENELITIAN}

Metode studi pustaka merupakan teknik pengumpulan data maupun informasi dengan menelaah dari berbagai sumber seperti buku, jurnal, karya ilmiah dan lain-lain. Pada penelitian ini peneliti menggunakan 6 (enam) studi pustaka yaitu:

1. Penelitian yang dilakukan oleh Untung Rahardja, Qurotul Aini, dan Marviola Hardini pada tahun 2018 dengan adanya Software Akuntansi Online dapat mempermudah akuntan dalam menginput data transaksi ke dalam sistem, di mana data transaksi tersebut dapat langsung di import ke dalam sistem sehingga lebih efisien [16].

2. Penelitian selanjutnya oleh In'am Fanany Z.A. pada tahun 2014, dengan adanya sistem akuntansi yang berbasis website mampu melayani transaksi dengan cara berkunjung atau secara online sehingga terciptanya fasilitas bagi pencatatan akuntansi [17].

3. Penelitian yang dilakukan oleh Untung Rahardja, Eka Purnama Harahap dan Dini intan (2018), dengan adanya pemanfaat Rinfosheet sebagai media penyimpanan laporan keuangan secara online, dan sudah tersimpan secara otomatis pada cloud[18].

4. Penelitian dilakukan oleh Ferry dan Kosadi dan Wajib Ginting (2018), software yang sudah berbasis internet sudah dilakukan, dan keuangan maupun akuntansi beberapa yang digunakan walau telah menggunakan android [19]

5. Penelitian yang dilakukan oleh Untung Rahardja,dkk (2018), penggunaan software akuntansi online berbasis cloud accounting untuk mempermudah dalam proses rekonsiliasi untuk menghasilkan laporan keuangan yang real-time dan akurat [20].

Dari 5 (lima) literature review diatas dapat disimpulkan telah banyak peneliti yang menggunakan akuntansi berbasis online atau cloud. Namun, dapat disimpulkan belum adanya peneliti yang menerapkan cloud accounting dalam proses laporan neraca.

Dalam penelitian ini, digunakan metode analisis sistem yaitu SWOT (Strength, Weakness, Opportunities, Threats) guna menyelesaikan permasalahan yang ada. Strength sebagai kekuatan pada sistem yang digunakan yaitu cloud accounting, weakness yaitu kelemahan pada software tersebut, opportunities yaitu peluang pada sistem tersebut dalam memanfaatkan teknologi yang ada. Dan ancaman pada cloud accounting tersebut dalam implementasi.

\begin{tabular}{|c|c|}
\hline STRENGTH & WEAKNESS \\
\hline $\begin{array}{l}\text { 1. Cloud accounting yang diterapkan pada } \\
\text { Perguruan Tinggi berbasis online. } \\
\text { 2. Data laporan terasip dengan baik dan online. } \\
\text { 3. Perguruan Tinggi Raharja berbasis } \\
\text { Teknologi Informasi. } \\
\text { 4. Dapat diakses dimana saja dan kapan saja } \\
\text { 5. Keamanan akun yang sangat baik. }\end{array}$ & $\begin{array}{l}\text { 1. Rekapan laporan neraca hanya dapat diakse } \\
\text { oleh super admin. } \\
\text { 2. Divisi keuangan beradaptasi dengan cloud } \\
\text { accounting. }\end{array}$ \\
\hline OPPORTUNITIES & THREATS \\
\hline $\begin{array}{l}\text { 1. Cloud accounting jurnal memudahkan divisi } \\
\text { keuangan. } \\
\text { 3. Adanya menu laporan secara keseluruhan } \\
\text { dalam mendapatkan informasi laporan } \\
\text { secara real-time. } \\
\text { 4. Efektif dan efisien. }\end{array}$ & $\begin{array}{l}\text { 1. Adanya Update pada cloud accounting } \\
\text { jurnal.id } \\
\text { 2. Perkembangan teknologi semakin } \\
\text { berkembang. } \\
\text { 3. Tidak adanya jaringan internet yang bisa } \\
\text { mengakses jurnal.id }\end{array}$ \\
\hline
\end{tabular}

Gbr 3. Analisis SWOT Laporan Neraca berbasis Cloud Accounting

\section{HASIL DAN PEMBAHASAN}

Dalam pembahasan ini akan dibahas mengenai analisa permasalahan yang ada yaitu proses laporan neraca yang masih perhitungan secara konvensional dan laporan yang didapatkan masih berupa lembaran kertas. Langkah terakhir adanya implementasi dengan menampilkan hasil screenshoot laporan neraca secara online pada cloud accounting jurnal.

Penyajian laporan keuangan bagian Neraca saat ini sudah baik, namun masih didapatkan secara manual atau konvensional. Manajemen laporan juga sudah cukup baik terhadap pimpinan setiap bulannya. Laporan bisa dimanfaatkan melalui pengiriman data melalui rinfo sebagai alat pendukung [21]. 


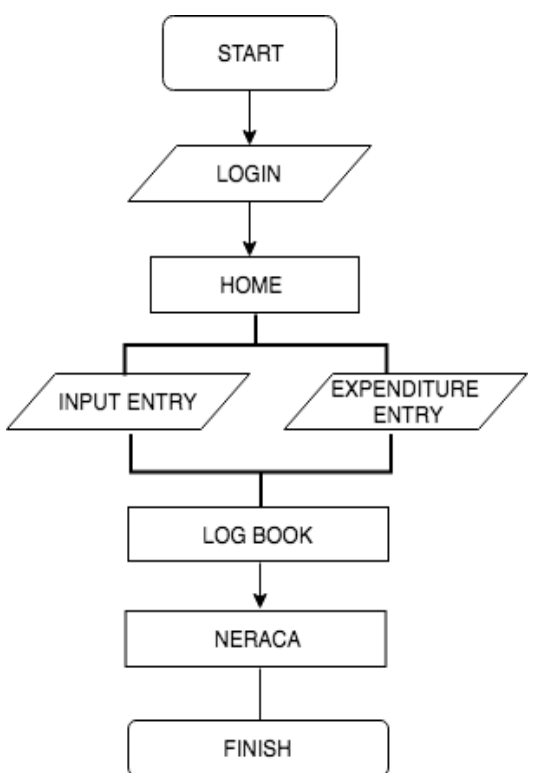

Gbr 4. Alur Laporan Neraca

Gambar 4 merupakan alur sistem laporan neraca yang masih menggunakan konvensional. Dimana data tersebut berasal dari data input dari mahasiswa dan pengeluaran dari Perguruan Tinggi. Kemudian data laporan pemasukan terdata dengan baik. Teknologi menjadi salah satu media transaksi pada e-commerce [22].

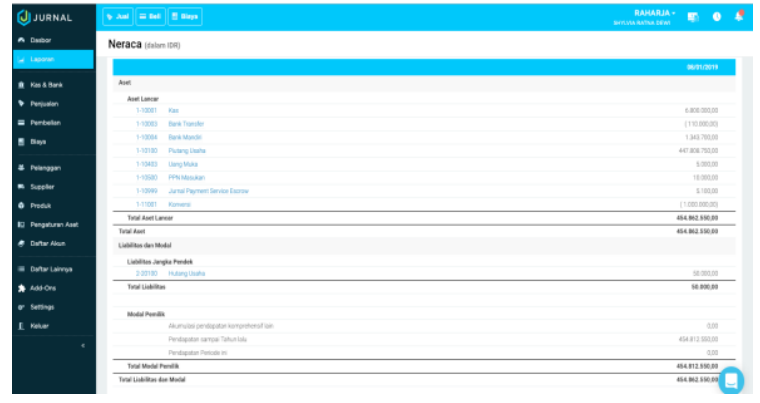

Gbr 5. Menu Laporan Neraca

Adanya Laporan Neraca yang diimplementasikan pada akun Raharja di cloud Accounting guna pendukung catatan keseluruhan laporan keuangan antara pemasukan dan pengeluaran. Serta manajemen laporan sudah terangkum sangat jelas terhadap pimpinan sehingga keuangan berjalan dengan lancar. Akuntan pun dengan mudah mendapatkan laporan tersebut tanpa harus menghitung secara manual atau konvensional.

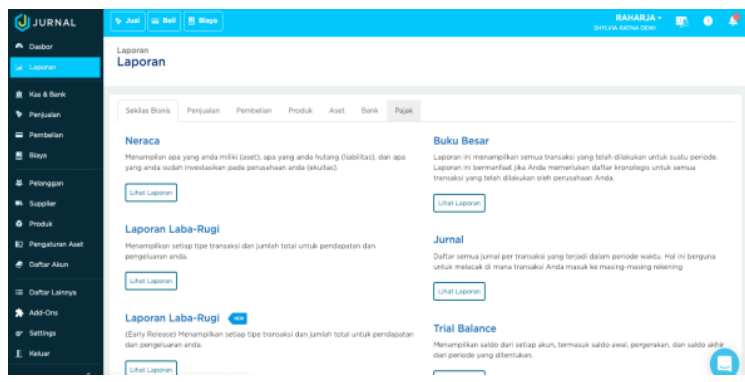

Gbr 6. Menu laporan

Menu Laporan pada software cloud Accounting berbagai macam laporan keuangan seperti neraca, laba rugi, buku besar dan lain-lain. Pada penelitian ini fokus terhadap laporan Neraca. Tab dari Neraca yang akan menghasilkan informasi dari Laporan Neraca secara cloud accounting pada akun jurnal Raharja. Hal tersebut mampu mempermudah mendapatkan informasi secara on time dan manajemen laporan guna mengambil keputusan [24] .

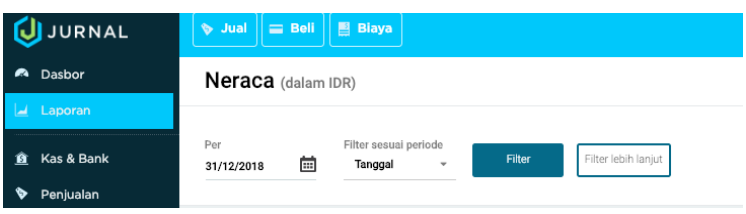

Gbr 7. Setting Waktu Laporan Neraca

Pada laporan Neraca terdapat setting waktu yang dibutuhkan. Dikarenakan laporan tiap bulannya pasti berbeda-beda. Manajemen pun bisa meminta data laporan neraca sewaktu-waktu dengan mudah. Demi dalam proses penyampaian informasi yang efektif, efisien dan cepat kepada civitas dibutuhkan media yang dapat menyampaikan secara secara ringkas [25].

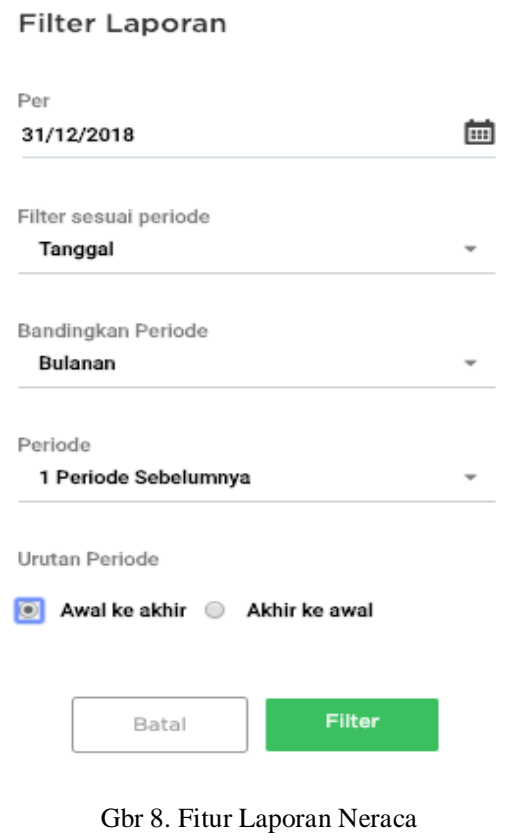

Terdapat 4 (empat) tab guna memfilter laporan sesuai yang diinginkan manajemen. Filter sesuai tanggal, dimana bisa mingguan atau perbulan. Kemudian tambahan fitur perbandingan 1 (satu) periode sebelumnya dengan periode sekarang. Adanya fitur ini memudahkan dalam mendapatkan laporan tanpa harus printout atau cetak kembali laporan neraca yang diinginkan [26] . 


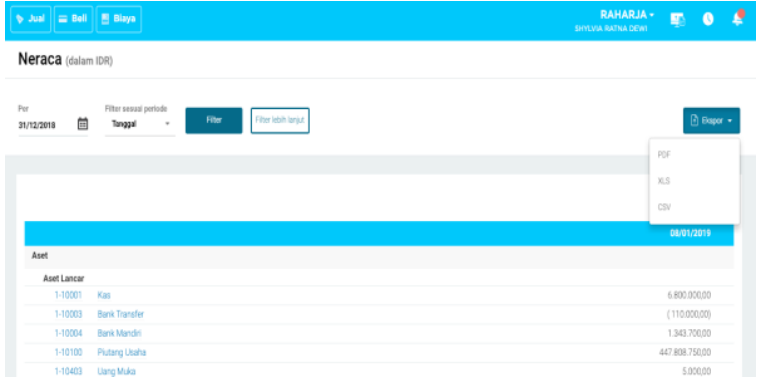

Gbr 9. Macam Tipe Hasil laporan Neraca

Dalam menyajikan informasi laporan neraca, manajemen tentunya menginginkan informasi yang ringkas dan mudah dipahami. Tak lupa juga hasil perhitungan secara otomatis yang didapatkan dari data pemasukan dan pengeluaran. Kualitas sebuah manajemen dalam bentuk laporan juga dapat terkait dengan standar dari instansi [27]. Data laporan Neraca bisa dilihat dalam bentuk format pdf, excel maupun csv.

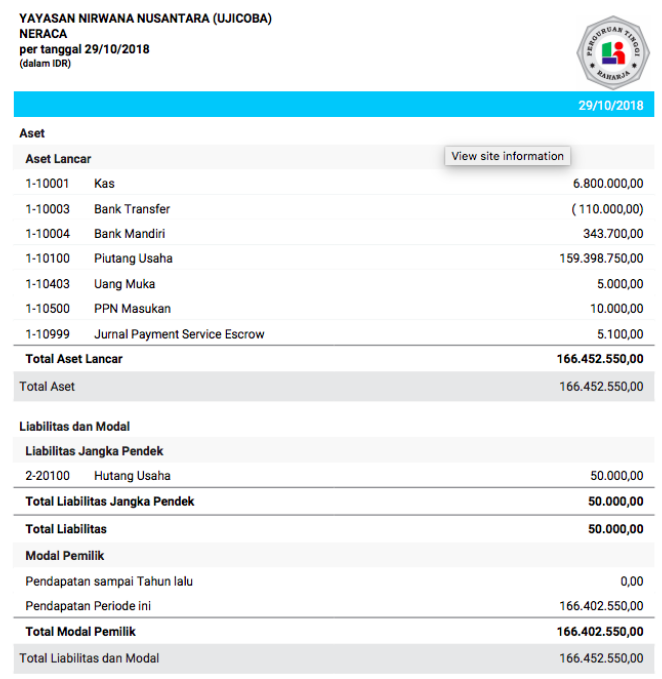

Gbr 10. Hasil Laporan Neraca Format PDF

\begin{tabular}{r|l|l|r|r|r}
\hline \hline & \multicolumn{1}{|c}{ A } & \multicolumn{1}{c}{ B } & \multicolumn{1}{c}{ C } & \multicolumn{1}{c}{ D } \\
\hline 1 & Nomor Akun Akun & $29 / 10 / 2018$ & & $30 / 09 / 2018$ \\
\hline 2 & $1-10001$ & Kas & 6800000 & & 6800000 \\
\hline 3 & $1-10003$ & Bank Transfer & -110000 & & -110000 \\
\hline 4 & $1-10004$ & Bank Mandiri & 343700 & & 343700 \\
\hline 5 & $1-10100$ & Piutang Usaha & 159398750 & $2.20 \%$ & 156013750 \\
\hline 6 & $1-10403$ & Uang Muka & 5000 & & 5000 \\
\hline 7 & $1-10500$ & PPN Masukan & 10000 & & 10000 \\
\hline 8 & $1-10999$ & Jurnal Payment Service Escrow & 5100 & & 5100 \\
\hline 9 & $2-20100$ & Hutang Usaha & 50000 & & 50000 \\
\hline 10 & & Current Period Earnings & 166402550 & $2.10 \%$ & 163017550 \\
\hline 11 & & & & & \\
\hline
\end{tabular}

Gbr 11. Hasil Laporan Neraca Format csv

\begin{tabular}{|c|c|c|c|c|c|}
\hline \multicolumn{6}{|c|}{$\begin{array}{lll}\text { C } & D & E\end{array}$} \\
\hline & \multirow{2}{*}{\multicolumn{5}{|c|}{ Yayasan Nirwana Nusantara (Ujicoba) }} \\
\hline 2 & & & & & \\
\hline 3 & \multicolumn{5}{|c|}{$\begin{array}{l}\text { Neraca } \\
\text { 30/09/2018 - 29/1/2018 }\end{array}$} \\
\hline & \multicolumn{5}{|c|}{$3010912018-2917012078$} \\
\hline & Tanggal & & $29 / 10 / 2018$ & & $30 / 09 / 2018$ \\
\hline & & & & & \\
\hline \multicolumn{6}{|c|}{$\begin{array}{l}\text { Aset } \\
\text { Aset Lancar }\end{array}$} \\
\hline 8 & $1-10001$ & Kas & $6,800,000.00$ & & $6,800,000.00$ \\
\hline 9 & $1-10003$ & Bank Transfer & $-110,000.00$ & & $-110,000.00$ \\
\hline 10 & $1-10004$ & Bank Mandiri & $343,700.00$ & & $343,700.00$ \\
\hline & $1-10100$ & Piutang Usaha & $1593988750.00^{\prime \prime}$ & $22 \%$ & $156,013,750,00$ \\
\hline & $1-10403$ & Uang Muka & $5,000.00$ & & $100,0,5,000,00$ \\
\hline & $1-10500$ & PPN Masukan & 10,00000 & & 10,00000 \\
\hline 14! & $\mid 1-10599$ & PFN Masuran & 10,00000 & & 5,00000 \\
\hline & $\begin{array}{l}\text { T-1-10999 } \\
\text { Total Aset }\end{array}$ & $\begin{array}{l}\text { Junal Payment Service Escrow } \\
\text { \& Lancar }\end{array}$ & $\begin{array}{r}5,160.00 \\
166,452,550.00^{\prime}\end{array}$ & $2.1 \%$ & $163,067,550.00$ \\
\hline \multicolumn{6}{|c|}{15 Total Aset Lancar } \\
\hline \multirow{2}{*}{\multicolumn{6}{|c|}{17 Depresiasi \& Amortisasi }} \\
\hline & \multirow{2}{*}{\multicolumn{2}{|c|}{$\begin{array}{l}\text { Lain-lain } \\
\text { Total Aset }\end{array}$}} & & & \\
\hline & & & $166,452,550,00^{\prime}$ & $2.1 \%$ & $163,067,550,00$ \\
\hline 20 & \multicolumn{5}{|c|}{$\begin{array}{l}\text { Total Aset } \\
\text { Liabilitas dan Modal }\end{array}$} \\
\hline \multicolumn{6}{|c|}{$\begin{array}{l}20 \text { Liabilitas dan Modal } \\
21 \text { Liabilitas Jangka Pendek }\end{array}$} \\
\hline \multirow{3}{*}{$\begin{array}{l}22 \\
23 \\
24\end{array}$} & $2-20100$ & Hutang Usaha & $50,000.00$ & & $50,000.00$ \\
\hline & \multirow{2}{*}{\multicolumn{2}{|c|}{ Liabilitas Jangka Panjang }} & & & \\
\hline & & & $50,000,00$ & & $50,000,00$ \\
\hline & \multicolumn{2}{|c|}{ Modal Pemilik } & & & \\
\hline (2) & & Pendanatan sampa Ta un lal & 000 & & 000 \\
\hline & \multirow{2}{*}{\multicolumn{2}{|c|}{$\begin{array}{l}\text { Pendapatan Periode ini } \\
\text { Total Modal Pemilik }\end{array}$}} & $166402550.00^{\prime \prime}$ & $2.1 \%$ & 163.017550 .00 \\
\hline & & & $\begin{array}{l}166,402,550.00^{\prime} \\
166\end{array}$ & $2.1 \%$ & $163,017,550.00$ \\
\hline 29 & \multirow{2}{*}{\multicolumn{2}{|c|}{ Total Liabilitas dan Modal }} & $166,452,550.00^{\prime}$ & $2.1 \%$ & $163,067,550.00$ \\
\hline 30 & & & & & \\
\hline
\end{tabular}

Gbr 12. Hasil Laporan Neraca Format excel

Dari hasil implementasi diatas Laporan keuangan Neraca yang dikelola oleh Perguruan Tinggi menggunakan cloud accounting mampu memudahkan akuntan dalam memperoleh laporan terhadap manajemen. Serta manajemen keuangan pada instansi Perguruan Tinggi sangat rapi dan tepat waktu. Selain itu, akuntan bisa menghemat waktu dalam perhitungan yang konvensional, dan sudah tidak dilakukan lagi karena adanya cloud accounting. Dan kebutuhan informasi dibutuhkan sesuai harapan manajemen guna mengambil keputusan dari permasalahan yang ada [28].

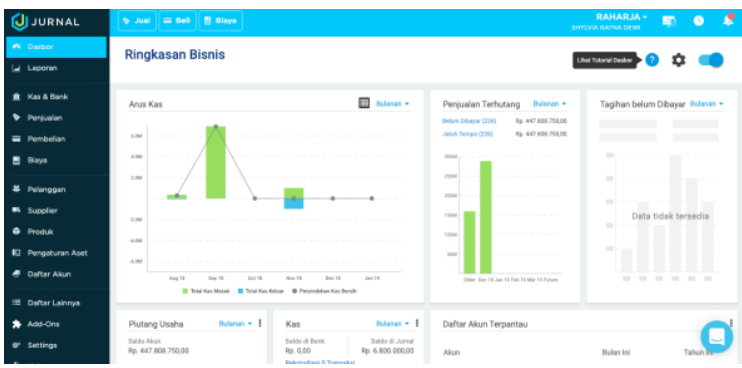

Gbr 13. Menu Dashboard

Pada gambar 13 dengan menggunakan cloud accounting jurnal.id terdapat menu dashboard yang berguna sebagai informasi keseluruhan namun ringkas. Dengan adanya Dashboard pada Web software cloud accounting dirasa mampu dapat memonitoring atau memantau kinerja user pada situs akuntansi online tersebut [28].

\section{PENUTUP}

Penggunaan teknologi informasi yang semakin canggih saat ini sudah seharusnya diterapkan pada Perguruan Tinggi. Termasuk kedalam bagian laporan keuangan yang dikelola oleh divisi keuangan. Laporan keuangan salah satunya yaitu laporan Neraca. Dimana terdapat 2 (dua) permasalahan yang sudah dijelaskan serta penyelesaiannya menggunakan metode analisis SWOT. Maka menghasilkan juga 2 (dua) kesimpulan yaitu: 
1. Adanya laporan neraca berbasis Cloud Accounting mampu mempermudah divisi keuangan dalam mendapatkan laporan secara real-time serta efektif dan efisien.

2. Divisi keuangan tidak perlu menghitung laporan neraca secara konvensional atau manual, sehingga dapat menimbulkan kekeliruan atau salah perhitungan dalam penjumlahan total.

Diharapkan dengan penggunaan sistem cloud accounting dalam laporan keuangan dalam bagian laporan neraca pada Perguruan Tinggi mampu bermanfaat bagi affiliasi lainnya dalam keuangan.

\section{REFERENSI}

[1] Rahardja, U., Aini, Q., \& Zuliana, S. R. (2016). METODE LEARNING MANAGEMENT SYSTEM (LMS) IDU UNTUK MENDUKUNG KEGIATAN BELAJAR MENGAJAR MIT PADA PERGURUAN TINGGI RAHARJA. CICES Journal, 2(2), 156-172.

[2] Yulianto, Y., Alfiah, F., Harahap, E. P., Pahad, B. A., Andriyanto, A., Azhari, I. A., \& Saputra, R. S. (2015). Analisa Peranan Teknologi Internet Sebagai Media Transaksi E-Commerce Dalam Meningkatkan Perkembangan Ekonomi. SEMNASTEKNOMEDIA ONLINE, 3(1), 4-1.

[3] Raharja, U., Lutfiani, N., \& Wardana, W. S. (2018) Penjadwalan Agenda Pelaksanaan Tridharma Perguruan Tinggi Secara Online Menggunakan Google Calendar.

[4] Mahaputra, I. P. U. R., \& Putra, I. W. (2014). Analisis Faktor-Faktor yang Mempengaruhi Kualitas Informasi Laporan Keuangan Pemerintah Daerah. E-Jurnal Akuntansi, 230-244

[5] Orniati, Y. (2009). Laporan Keuangan Sebagai Alat Untuk Menilai Kinerja Keuangan. Jurnal Ekonomi Bisnis, 14(3), 206-213.

[6] Murdoko Sudarmadji, A., \& Sularto, L. (2007, August). Pengaruh ukuran perusahaan, profitabilitas, leverage, dan tipe kepemilikan perusahaan terhadap luas voluntary disclosure laporan keuangan tahunan. In Seminar Ilmiah Nasional PESAT 2007. Lembaga Penelitian Universitas Gunadarma.

[7] Arfianti, D., \& Kawedar, W. (2011). Analisis faktor-faktor yang mempengaruhi nilai informasi pelaporan keuangan pemerintah daerah (Studi pada satuan kerja perangkat daerah di kabupaten Batang) (Doctoral dissertation, Universitas Diponegoro).

[8] Mulyono, T. P. (2001). Manajemen Perkreditan bagi Bank Komersil Edisi Kedua. Jokjakarta: BPFE.

[9] Saraswati, R. A. (2012). Peranan Analisis Laporan Keuangan, Penilaian Prinsip 5C Calon Debitur dan Pengawasan Kredit terhadap Efektivitas Pemberian Kredit pada PD BPR Bank Pasar Kabupaten Temanggung. Nominal, Barometer Riset Akuntansi dan Manajemen, 1(1)

[10] Jurnal., "Menu About", https://www.jurnal.id/id/about us diakses tgl 27 oktober 2018

[11] Aini, Q., Rahardja, U., Moeins, A., \& Wardani, A. M (2018). Penerapan Data Market Query (DMQ) pada Sistem Penilaian Berbasis Yii Framework. InfoTekJar: Jurnal Nasional Informatika dan Teknologi Jaringan, 3(1), 26-31.

[12] Rahmani, A, 2018, Kenali 7 Ciri-Ciri Ini Sebelum Memilih Software Akuntansi Online, https://www.jurnal.id/id/blog/2018/kenali-7-ciri-ciri-inisebelum-memilih-softwareakuntansi-online diakses tgl 27 oktober 2018

[13] Sudaryati, D., \& Zahro, N. I. (2010). Auditing Forensik dan Value For Money Audit. Sosial dan Budaya.

[14] Rahardja, U., Aini, Q., \& Santoso, N. P. L. (2018) Pengintegrasian YII Framework Berbasis API pada Sistem Penilaian Absensi. SISFOTENIKA, 8(2), 140-152.

[15] Rahardja, U., Aini, Q., \& Khoirunisa, A. (2017) Implementasi Business Intelligence Menggunakan Highchart pada Sistem Penilaian Absensi berbasis YII Framework CSRID (Computer Science Research and Its Development Journal), 9(2), 115-124.
[16] Rahardja, U., Aini, Q., \& Hardini, M. (2018). PENERAPAN SOFTWARE AKUNTANSI ONLINE SEBAGAI PENUNJANG PENCATATAN LAPORAN KEUANGAN. SISFOTENIKA, 8(2), 176-187.

[17] FANANY, Z. (2014). Perancangan Sistem Informasi Akuntansi Multi-Tenant pada Perusahaan Dagang Berbasis Cloud Computing Website dengan Metode Rapid Application Development (Doctoral dissertation, Prodi Akuntansi Unika Soegijapranata)

[18] Rahardja, U., Harahap, E. P., \& Pratiwi, D. I. (2018). Pemanfaatan RinfoSheet Sebagai Media Informasi Laporan Penjualan Barang pada Raharja Internet Cafe. Jurnal Ilmiah Teknologi Informasi Asia, 12(1), 65-74

[19] Kosadi, F., \& Ginting, W. (2018). ANALISA DESKRIPTIF ATAS PENCATATAN TRANSAKSI, PENGGUNAAN APLIKASI (SOFTWARE) DAN PEMBUATAN LAPORAN KEUANGAN PADA ENTITAS MIKRO KECIL DAN MENENGAH (EMKM). E-Jurnal STIE INABA, 17(3), 3346.

[20] Rahardja, U., Aini, Q., Azizah, N., \& Santoso, N. P. L. (2018). Efektivitas Akuntansi Online dalam Menunjang Proses Rekonsiliasi. Nusantara Journal of Computers and its Applications, 3(2).

[21] Rahardja, U., Tiara, K., \& Wijaya, R. I. T. (2014). Penerapan Rinfo Sebagai Media Pendukung Untuk Proses Pembelajaran Pada Perguruan Tinggi Raharja. CCIT Journal, 8(1), 101115.

[22] Yulianto, Y., Alfiah, F., Harahap, E. P., Pahad, B. A., Andriyanto, A., Azhari, I. A., \& Saputra, R. S. (2015). Analisa Peranan Teknologi Internet Sebagai Media Transaksi E-Commerce Dalam Meningkatkan Perkembangan Ekonomi. SEMNASTEKNOMEDIA ONLINE, 3(1), 4-1.

[23] Handayani, I., Kusumahati, H., \& Badriah, A. N. (2017). Pemanfaatan Google Spreadsheet Sebagai Media Pembuatan Dashboard pada Official Site iFacility di Perguruan Tinggi. Sisfotenika, 7(2), 177-186.

[24] Rahardja, U., Aini, Q., \& Faradilla, F. (2018). IMPLEMENTASI VIEWBOARD BERBASIS INTERAKTIF JAVASCRIPT CHARTS PADA WEBSITE E-COMMERCE PERGURUAN TINGGI. Jurnal Dinamika Informatika, 7(2), 1-17.

[25] Rahardja, U., Harahap, E. P., \& Pratiwi, D. I. (2018). Pemanfaatan RinfoSheet Sebagai Media Informasi Laporan Penjualan Barang pada Raharja Internet Cafe. Jurnal Ilmiah Teknologi Informasi Asia, 12(1), 65-74.

[26] Raharja, U., Harahap, E. P., \& Devi, R. E. C. (2018). Pengaruh Pelayanan dan Fasilitas pada Raharja Internet Cafe Terhadap Kegiatan Perkuliahan Pada Perguruan Tinggi. Jurnal Teknoinfo, 12(2), 60-65.

[27] Rahardja, U., Lutfiani, N., \& Rahmawati, R. (2018). Persepsi Mahasiswa Terhadap Berita Pada Website APTISI. SISFOTENIKA, 8(2), 117-127.

[28] Rahardja, U., Aini, Q., \& Khoirunisa, A. (2018). Monitoring Kinerja User Akuntan Menggunakan Dashboard Pada Web Based Accounting Online di Perguruan Tinggi. SATIN-Sains dan Teknologi Informasi, 4(2), 58-62. 